\title{
Problems of translating English and German proverbs into Russian: the comparative aspect
}

\author{
Oksana Sorokina ${ }^{1, *}$, Irina Krasnova $^{1}$, Veronika Shabanova ${ }^{1}$ \\ ${ }^{1}$ Moscow State Region University, 10a, Radio Street, 105005, Moscow, Russia
}

\begin{abstract}
This article presents the results of the comparative analysis of translatability of English and German proverbs into Russian, which allows to discover specific features of communicants within various linguocultures, which is one of the priority areas of modern linguistic research. The work emphasizes that due to their figurativeness and ethnocultural specificity, proverbs are a striking example of untranslatability or difficult translatability. This determines the significance of the research under discussion - the increasing need of society for high-quality translation and training of qualified translators. Despite a sufficient number of works devoted to paremiology, the major attention is paid to the semantic and structural features of proverbs in different languages under the absence of comprehensive studies on the translation of proverbial units, which hampers the complete study of the translation problem of paremias. The purpose of the study is to identify close correlations between the proverbs of different languages based on the comparative analysis of the linguistic material of the English, German and Russian languages and a comparison of approaches to the solutions of the problems of their translation. The accomplishment of the stated purpose predetermined the objectives of the study: basing on the analysis of experience concerning proverbs that was accumulated by modern linguistics, to reveal the notion of a proverb; to study the reflection of the linguistic world-picture in the proverbs of the English, German and Russian languages, as well as to conduct the comparative translation analysis. As a result, the authors were able to identify and describe the difficulties encountered in translating English and German proverbs into Russian. The article presents the author's classification of the studied phraseological units in accordance with their translatability from the source language into the target language. All research results are supported by the statistical data.
\end{abstract}

\section{Introduction. A proverb regarded as a notion}

In recent years, digital technologies have become ingrained in people's everyday lives in almost all areas: from the volume of received and processed information to social networks, electronic payments and online public services. The whole life is permeated with a huge number of new technologies and media gadgets that are frequently eager to think for a person using an incredible amount of knowledge [1]. However, despite this, one of the most

\footnotetext{
*Corresponding author: Oxana_Moskau@mail.ru
} 
important problems for modern researchers is the preservation and study of the linguistic heritage that preserves the life experience of various ethno-social societies. Proverbs, regarded as culturally marked set units, that reflect extralinguistic reality, are a vivid example of the interinfluence of language and culture. Proverbs reflect the communicative rules and traditions of a particular linguocultural community [2]. Thus, it is necessary to emphasize the importance of purposeful study of proverbs in the context of training of future translators and linguists. As Dance D. notes, "... a person who can argue their position using figurative expressions that reflect folk wisdom, obtain an advantage." [3].

The article is devoted to a comparative analysis of the translatability of the English and German proverbs into Russian in order to identify close correlations between proverbial phraseological units of different languages.

The object of this study is the proverbs of the English, German and Russian languages, taken from phrase books and electronic sources for the comparative analysis. In the course of work, more than 400 proverbs has been considered.

The subject of the research is the peculiarities of translation of English and German proverbs into Russian and the variety of options of overcoming the emerging translation difficulties.

Due to the widespread interest of researchers in such a phenomenon as proverbial phraseological units, there are different approaches to their consideration. For instance, folklorists consider a proverb to be a certain proposition that contains folk wisdom accumulated over the centuries $[4,5]$. In their works, proponents of the linguistic approach regard proverbs as communicative phraseological units, which is the object and the key notion of phraseology [6]. Within linguocultural studies, a proverb is defined as the linguocultural text, which expresses the culture of a certain community, describes important historical moments, traditions, morals and customs of the people speaking the corresponding language, in a concentrated form. "Cultural linguistics is based on the study of the cumulative function of a language, in which language is regarded as a repository and a means of a transfer of extralinguistic collective wisdom, and is most clearly manifested in proverbs and sayings" [7].

In the research under discussion, when studying the translatability of proverbs from the source language (SL) into the target language (TL), a proverb is considered to be a linguocultural text, the translation of which must accord with the norms of equivalence of the source text (ST) and the translated text (TT) $[8,9]$ and is defined as a communicative phraseological speech unit (CPSU) that expresses a completed utterance, which usually has multiple meanings and often contains a didactic content.

\section{A proverb regarded as a phenomenon}

There are no limits to the use of proverbs. Proverbs are quite often found in newspaper articles, headlines, public speeches and commercials. During the translation of texts of various functional styles, the translator frequently encounters the major problem of translation of proverbial units which is the search for approaches and methods of transfer of cultural characteristics contained within a proverb. Proverbial units allow to transfer the "realities of life" in different cultures [10]. In a set figurative form, proverbs convey its social reality, which is received and recognized by all members of the ethno-cultural community, while TL serves as a tool-code for social reality and produces its own unique version [11].

According to the results of the comparative analysis of the variants of the translation of proverbs from English and German into Russian, the major causes of translation difficulties were identified. They are discrepancies between the languages in the context of systems, norms, usage, as well as the discrepancy between pre-information resources of native 
speakers of the SL and TL. In addition, due to the distinctive features of proverbial CPSUs, the factors that influence the translation process, such as the dynamics of ST, should be taken into account. Thus, the conversions of the original CPSUs that are motivated by the pursuance of the harmony of TT, as well as dependent on the rhythmic pattern of the CPSUs and defined as transformations with concealed motivation, have been pointed out [12].

According to the author's calculations, the major transformational changes of proverbs during the translation are caused by the usage discrepancies between the languages, which is primarily associated with the discrepancy between the speech customs of different nations. A slightly smaller number of proverb transformations as a result of translation is carried out due to the differences between linguistic norms, and transformations associated with systemic distinctions between the languages and the discrepancy of pre-information resources of native speakers of the SL and TL are rarely conducted.

The diagram (Figure 1) displays the percentage of the identified causes of the translation transformations of the proverbial CPSUs.

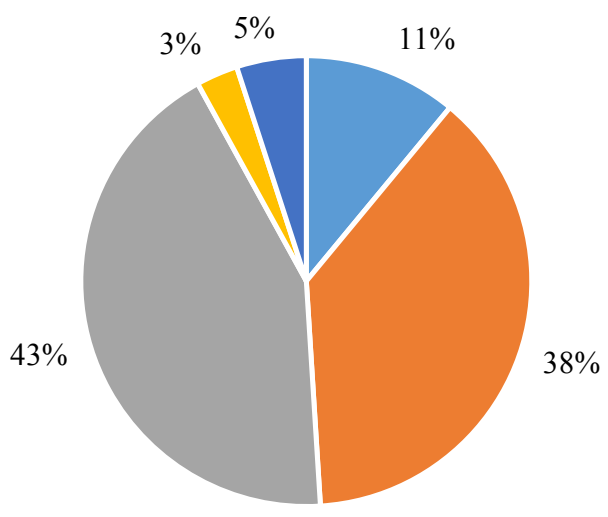

$$
\begin{aligned}
& \text { - System differences between SL } \\
& \text { and TL } \\
& \text { - Differences between norms of } \\
& \text { SL and TL } \\
& \text { - Differences between the usage } \\
& \text { of SL and TL } \\
& \text { - Transformation with concealed } \\
& \text { motivation } \\
& \text { - Differences between the pre- } \\
& \text { information resources of the } \\
& \text { native speakers of SL and TL }
\end{aligned}
$$

Fig. 1. Causes of translation transformations of proverbs.

As a result of the comparative analysis of proverbs and their translations, the major problems occurring in the process of translation of the CPSUs have been discovered as well [13]:

1. Problems associated with discrepancies between the grammatical and morphological structure of the SL and TL, for instance:

- The double negation in Russian and its absence in German and English;

- A free word order in Russian and a fixed word order in the German and English languages;

- Wider word-formation variety of the German language compared to Russian;

2. Translation problems associated with discrepancies between lexical structure of the SL and TL, for example:

- Homonymy and polysemy of words in the English and German languages;

- The problem of equivalent translation of phraseological expressions;

- The problem of translation of non-equivalent vocabulary, which is associated with the cultural features and customs of the English- and German-speaking nations.

3. Translation problems associated with the discrepancy between the stylistic structure of the SL and TL, for instance:

- The problem of translation of a special style of proverbs: metaphors, irony, etc. 
4. The particular difficulty is the transfer of the proverb's rhyme in the process of its translation from SL to TL, which causes the phonemic loss. For instance,

Augen auf! Kauf ist Kauf! (lit. Open your eyes! A purchase is just a purchase) [14].

На ошибках учатся (lit. Learn from past mistakes) [15].

East or West, home is best [16].

B гостях хорошо, а дома лучше (lit. Being a guest is good, but being at home is better) [15].

5. Difficulties in translation of the CPSUs, characterized by certain intonation patterns, in which the phrasal stress is rigidly fixed, for example:

Alles vergeht, Wahrheit besteht (lit. Everything passes, but truth remains) [14].

Все минется, одна правда останется (lit. Everything will pass, except for the truth). [15]

As a result of the comparative analysis of proverbs and their translations into Russian, the studied CPSUs were divided into four major categories in accordance with the degree of translatability. These categories are:

1) The CPSUs that have the exact equivalents when translated from English and German into Russian;

2) The CPSUs with structural-level transformations in the translation;

3) The CPSUs with content transformations in the translation;

4) The CPSUs that do not have an equivalent in the target language.

In the first category, all proverbs have a Russian equivalent, which is a literal translation of the CPSU. Most commonly, such equivalents are associated with the fact that proverbial matches are found in the so-called international CPSUs, borrowed by the English, German, and Russian languages from a common source (for instance, borrowings from an ancient language; Bible, or catch phrases that have become proverbs). For example, English and German proverbs have the exact equivalents when translated from German and English into Russian:

He that doesn't work, neither shall he eat [16].

Wer nicht arbeitet soll auch nicht essen [14].

Kто не работает, тот не ест [15].

In the second category, the translation method is different: the translator needs to carry out certain ST transformations in order to preserve the meaning of the proverb. For example, the English and German proverbs

When the cat is away, the mice will play [16].

Wenn die Katze fort ist, tanzen die Mäuse (lit. When there is no cat nearby, the mice dance) [14].

subjected to some structural-semantic changes in the translation. The Russian equivalent of the proverb: Без кота мышиам раздолье (lit. Without a cat, mice are free) [15].

In the third category, the set of characteristics which the situation in the proverb is described with is changed. For example, the English and German proverbs

He that will thrive must rise at five [16].

Früh zu Bett, früh wieder auf, macht gesund und reich in Kauf (lit. the earlier you go to bed, the earlier you wake up - the healthier and more successful in trade you will be) [17].

undergo situational-semantic changes in the translation. The Russian version of the proverb is Встанешь пораньше, шагнешь подальше (lit. The earlier you get up, the further you will go) [15].

The fourth category is a group of proverbs that do not have equivalents in TL. In these cases, the translator has to apply the descriptive approach to the translation. Although it is the only way to solve the translation problem, unfortunately, it entails the loss of nuances of the idea of the proverb. For instance,

Hans Ungeschick hat selten Glück (lit. Clumsy Hans is rarely lucky) [14]. 
На бедного Макара все шишки летят (lit. All cones are thrown at poor Makar).

Along with the above-listed major categories of the considered CPSUs, certain subgroups were identified.

One of them is the proverbial CPSUs, the translation of which presents certain difficulties for the translator, referred to as anti-proverbs or pseudo-proverbs in the linguistic literature. They denote modified, "modernized" versions of the original proverbs, which, while maintaining the structure and form of the traditional CPSUs, acquire a different meaning. Such CPSUs are the result of reflection of cultural-aesthetic and sociopolitical changes in society in the language. For example, the traditional German proverb, which carries the meaning of disapproval of careless work of poor quality

Ohne Fleiß kein Preis (lit. No pain no gain) [14].

has a variation

Ohne Preis kein Fleiß (lit. No diligence without price) [18],

emphasizing the refusal to work for free or work for a pittance.

The emergence of pseudo-proverbs could also be caused by the rule of expressiveness. Advertising slogans, headings of journalistic texts, headlines on web pages contain many pseudo-proverbs, which are a powerful tool for providing the text with a certain expressive effect:

No police like Holmes,

Man proposes - but not always marriage

Alte Liebe kostet nichts (lit. Old love costs nothing) [18].

Geld allein macht nicht glücklich, doch es beruhigt die Nerven (lit. Money alone doesn't make you happy, but it calms your nerves) [18].

Another subgroup consists of individual author's transformations of the traditional CPSUs. In the works of art, such occasional author's versions of the CPSUs could be either contextually determined or related to the author's desire to have a greater emotional impact on the reader or to express his/her own evaluative attitude to the events, facts or characters of the work. Moreover, the range of such author's transformations is very wide: from the introduction of new lexico-grammatical components in the traditional CPSU, division of the original CPSU into separate components that are the carriers of the associated meaning of the entire CPSU; usage of part of the components of the original CPSU, inversion of the component, elliptical usage, to the use of a blending technique that synthesizes the meaning of several CPSUs, for example:

- Ich habe A gesagt und B und wohl auch $K$ und L, und nun glaubst du natürlich, mein Lieber, das wird so weiter gehen das ganze Alphabet durch. Aber da irrst du. Mwerde ich nicht mehr sagen. Meine Verblendung ist zu Ende, merkwürdigerweise gerade vor dem $M$.

The example demonstrated above is a striking illustration of the method of expansion of the component combination of the original German CPSU "Wer A sagt, muss auch B sagen" (the Russian equivalent is "Взялся за гуж, не говори, что не дюж" (lit. If you took the tug, don't say that you are not strong enough)).

Here are more examples of the individual author's transformations of the traditional English CPSUs:

Like it or not, you cannot step into the same river twice.

This is Hong Kong! All that glitters here is gold!

The translation of the above-listed subgroups of CPSUs requires the translator to have impeccable profound knowledge of the proverbs of the SL and TL, as well as to be able to understand the implicit meaning added by the author through the pseudo-proverbs.

The percentage of the identified categories is demonstrated in the diagram (Figure 2) 


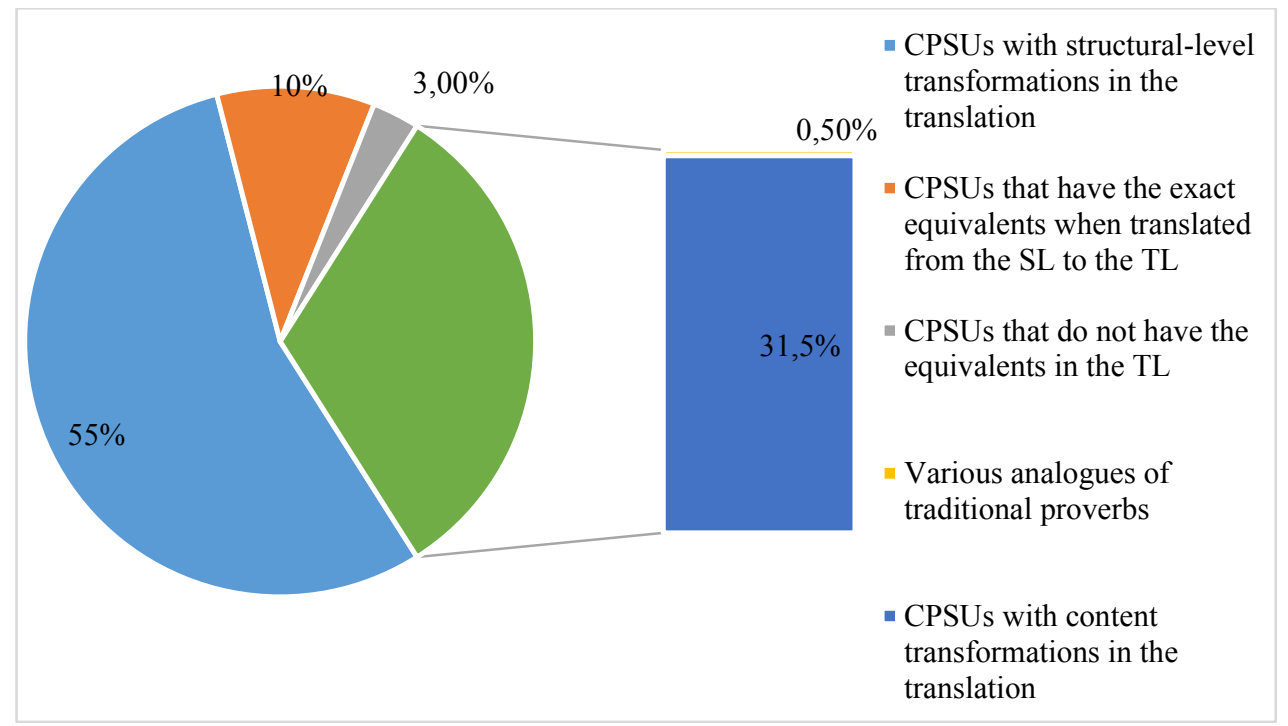

Fig. 2. The percentage of the identified categories.

In the process of translation from both languages into Russian, proverbs with certain structural-semantic changes in the translation prevailed, which indicates a common understanding of the core values of the speakers of SL and TL, as well as the proximity of cultures of native speakers of the English, German and Russian languages. Proverbs that do not have the equivalent in the target language displayed the lowest number, which indicates slight differences between the linguistic reflection of the world-view of the nations.

In addition to general analysis, the comparative analysis of separate languages pairs: English-Russian and German-Russian, was of great interest in the course of work. It was discovered that the English proverbs have the greatest number of equivalents with the Russian language. Situations in which a literal translation of the proverb is possible indicate that the cultures of the speakers of the SL and TL possess a common connection, on the basis of which the proverb was formed. The data obtained is presented in summary Table 1.

Table 1. The categories of proverbs according to their translatability from the English and German languages into Russian.

\begin{tabular}{|l|l|l|l|}
\hline \multicolumn{1}{|c|}{ № } & \multicolumn{1}{|c|}{ Category } & $\begin{array}{c}\text { The English } \\
\text { language \% }\end{array}$ & \multicolumn{1}{|c|}{$\begin{array}{c}\text { The German } \\
\text { language \% }\end{array}$} \\
\hline 1. & $\begin{array}{l}\text { CPSUs that have the exact equivalents when translated } \\
\text { from the SL to the TL }\end{array}$ & $10 \%$ & $7 \%$ \\
\hline 2. & $\begin{array}{l}\text { CPSUs with structural-level transformations in the } \\
\text { translation }\end{array}$ & $56 \%$ & $57 \%$ \\
\hline 3. & CPSUs with content transformations in the translation & $32 \%$ & $33 \%$ \\
\hline 3.1 & Various analogues of traditional proverbs & $0.5 \%$ & $0.7 \%$ \\
\hline $3.1 . \mathrm{a}$ & individual author's transformations of the CPSUs & $0.15 \%$ & $0.25 \%$ \\
\hline $3.1 . \mathrm{b}$ & anti-proverbs & $0.35 \%$ & $0.45 \%$ \\
\hline 3.2. & $\begin{array}{l}\text { CPSUs with situational-semantic transformations in the } \\
\text { translation }\end{array}$ & $31.5 \%$ & $32.3 \%$ \\
\hline 4. & CPSUs that do not have the equivalents in the TL & $2 \%$ & $3 \%$ \\
\hline
\end{tabular}




\section{Conclusion}

The comparative translation analysis of proverbial units in the English, German and Russian languages allowed to establish the similarity of forms of expression of thought in these ethno-cultures, which is explained by the universality of thinking as a result of the historical community [19]. The use of a wide range of translation techniques, such as structural-semantic transformations, content transformations, and profound transformations allows to translate the national color of metaphorical images of German and English proverbs into the Russian linguistic culture, as well as to preserve their ethnic-language specificity.

The conducted linguistic comparative analysis of the ST and the TT allowed to draw conclusions regarding the frequency of application of certain categories of identified translation transformations in the process of translation of proverbial CPSUs. According to the results of the study, the most frequent translation techniques for the translation of proverbial CPSUs from both English and German are the structural-level transformations, i.e. transformations affecting only the structure of the original CPSU. This could be explained by the dissonance at the morphological, syntactic, or lexical levels of the language. Such transformations have the least impact on the quality of translation of the original CPSU and are the most imperceptible to the translator. According to the calculations, content transformations also display a fairly large frequency of translation transformations, but the level of depth of such transformations is much greater. Among these transformations, functionally adequate substitutions, explication and implication techniques, descriptive translation, as well as profound transformations, i.e. transformations, the use of which entails not only the change in the structure or the replacement of the form of expression of the content of the original CPSU, but also the transformation of the model of thought of the original CPSU, have been identified.

The preservation of the motivation, sufficiency, and limitation of the translation transformations allows the translator to resolve the objective difference that often emerges during the translation process between the translation variants of the content of the original CPSU through the TL system and adaptation of the created CPSU to the linguistic-ethnic communicative competence of the TT recipient.

The translation of proverbial CPSUs requires the translator to be highly skilled, to possess profound extralinguistic background knowledge, to not only take into account the general linguistic characteristics of CPSUs, but also to regard CPSUs as poetic miniatures. The elaborate analysis of semantic images contributes to the translator's closer understanding of distinctive features of mindsets that are subtly planted in the figurative images of proverbs. Thus, special attention should be paid to such subgroups of proverbial CPSUs as pseudo-proverbs and individual author's transformations of CPSUs, the translation of which should be approached creatively. Since, in this case, by interpreting the proverbs of the SL and TL, the translator creates a "creolized" proverbial CPSU, which allows the author's view of the world to find a different, colorful and unique "packaging", assembled from the content available in the TL.

\section{References}

1. W. Blum, globale Gehirn, Die Zeit, https://www.zeit.de/2001/40/200140_global_brain.xml

2. O.D. Tarasova, N.A. Skitina, Filologicheskie nauki. Voprosy teorii i praktiki 10-1(88), 162 (2018)

3. D.C. Dance, From my people: 400 years of African American folklore (New York, NY, 
W.W. Norton and Company, 2002)

4. A.A. Potebnia, Mysl' i iazyk (M., Labirint, 1999)

5. V.P. Zhukov, A.V. Zhukov, Russkaia frazeologiia Ucheb. posobie (M., Vysshaia shkola, 2006)

6. V.A. Kunin, Pis'mennyi perevod s russkogo iazyka na angliiskii (M., Vysshaia shkola, 1964)

7. V.L. Maslova, Lingvokul'turologiia (M., Izdatel'skii tsentr «Akademiia», 2001)

8. I.A. Bakushkina, Izmerenie semantiko-strukturnoi analogichnosti originala i perevoda (na materiale perevodov tekstov razlichnykh zhanrov s nemetskogo iazyka na russkii) Dissertatsiia na soiskanie uchenoi stepeni kandidata filologicheskikh nauk (Moscow, 2005)

9. I.A. Krasnova, M.G. Mirianashvili, O.O. Sorokina, Vestnik Moskovskogo gosudarstvennogo oblastnogo universiteta. Seriia: Lingvistika 2, 128 (2019)

10. N.A. Skitina, N.V. Poliakova, V.P. Shabanova, Filologicheskie nauki. Voprosy teorii i praktiki 12(8), 262 (2019)

11. A. Solntseva, Evoliutsiia romanskikh iazykov: ot iazyka narodnosti k iazyku natsii. Materialy mezhdunarodnoi nauchnoi konferentsii (2018)

12. O.O. Karabanova, Perevodcheskie transformatsii kak poniatie i iavlenie. Diss. ... kand. filologich. Nauk (M., 2000)

13. I.A. Krasnova, O.O. Sorokina, Vestnik Moskovskogo gosudarstvennogo oblastnogo universiteta (Elektronnyi zhurnal) 1 (2017) www.evestnik-mgou.ru

14. Sprichworte und Zitate, http://www.sprichworte-und-zitate.de

15. V.P. Zhukov, Slovar' russkikh poslovits i pogovorok (M., Russkii iazyk, 2000)

16. The free dictionary. Idioms and phrases, http://idioms.thefreedictionary.com

17. Duden, Bd. 11. Redewendungen und sprichwörtliche Redensarten (Der Duden in 12 Bänden) (Dudenverlag, 2002)

18. W. Mieder, Verdrehte Weisheiten, Antisprichwörter aus Literatur und Medien. Gesellschaft für deutsche Sprache (Hrsg.) (Wisbaden, Quelle und Meyer, 1998)

19. I.N. Filippova, Sravnitel'naia tipologiia nemetskogo i russkogo iazykov (M., Flinta, Nauka, 2012)

20. N.L. Adamiia, Russko-anglo-nemetskiy slovar' poslovits, pogovorok, krylatykh slov $i$ Bibleyskikh izrecheniy (M., Nauka: Flinta, 2006)

21. M.V. Bukovskaia, S.I. Vial'tseva, Z.I. Dubianskaia, Slovar' upotrebitel'nykh angliyskikh poslovits (M., Russkiy yazyk, 1990)

22. V.I. Dal, Poslovitsy russkogo naroda (M., Izd-vo Eksmo, Izd-vo NNN, 2003)

23. A.K. Gatilova, Innovatsionnye voprosy teorii i praktiki mezhkul'turnoi kommunikatsii materialy Vserossiiskoi nauchno-prakticheskoi konferentsii (ILiMK MGOU, 2014)

24. D. Karlheinz, Text und autorenspezifische Phraseologismen. Beitrage zur allgemeinen und germanischen Phraseologieforschung (Oulu, 1987)

25. A.A. Kibrik, Iazykovaia kartina mira. Entsiklopediia Krugosvet, http://www.krugosvet.ru/node/41681

26. V.N. Komissarov, Sovremennoe perevodovedenie (M., ETS, 2002)

27. O.A. Kornilov, Iazykovye kartiny mira kak proizvodnye natsional'nykh mentalitetov (M., CheRo, 2003)

28. L.K. Latyshev, Tekhnologiia perevoda: uchebnik i praktikum dlia akademicheskogo 
bakalavriata (M., Izdatel'stvo Iurait, 2017)

29. A.B. Lokhovits, Russko-nemetskii slovar' (Gos. izd-vo inostrannykh i natsional'nykh slovarei, 1943)

30. Na latyni, pro latyn', http://www.latinpro.info/latin_proverbs_v.php

31. S.I. Ozhegov, N.Iu. Shvedova, Tolkovyi slovar' russkogo iazyka (M., Azbukovnik, 1999)

32. Z.D. Popova, I.A. Sternin, Ocherki po kognitivnoi lingvistike (Voronezh, 2001)

33. Ia.I. Retsker, Teoriia perevoda i perevodcheskaia praktika (M., Auditoriia, 2016)

34. A.D. Shveitser, Teoriia perevoda: Status, problemy, aspekty (M., Nauka, 1988)

35. R. Stolze, Übersetzungstheorien. Eine Einführung (Tübingen, Narr Verlag, 2008)

36. M.Ia. Tsvilling, Russko-nemetskii slovar' poslovits i pogovorok (M., Russkii iazyk, 1984)

37. L.V. Vasil'eva, Kratkost' - dusha ostroumiya. Angliyskiye poslovitsy, pogovorki, krylatyye vyrazheniya (M., ZAO Tsentrpoligraf, 2006)

38. V.S. Vinogradov, Vvedenie v perevodovedenie (M., IOSO RAO, 2001) 